\title{
Analysis Of Students 'Ability To Complete The Problem Of Geometry And Building Side Rooms Based On Van Hiele Geometry Thoughts On Class IX Students Of SMP PGRI Poncokusumo Malang
}

\author{
Nikodemus Yiwa Njurumana, Muhammad Baidawi, Sri Rahayuningsih
}

Program studi pendidikan matematika, Universitas Wisnuwardhana Malang nikodemusnjurumana@gmail.com, m.baidawi@wisnuwardhana.ac.id, ning.rahayu.82@gmail.com

\begin{abstract}
The purpose of this study was to describe the ability of students' level of thinking in solving geometry problems with curved side spaces based on Van Hiele's level of geometry thinking in class IX students of SMP PGRI Poncokusumo Malang.

This research method is descriptive qualitative research. In this case the analysis of the description of the level of thinking of students in solving geometry problems arising from the curved side space based on Van Hiele's theory. The research subjects taken were grade IX students of Poncokusumo Middle School, totaling 11 students. The instruments used were test, interview and documentation instruments. The results of the geometry problem analysis test show that the curvature shows that students have improved from previous studies where at level 0 and 1 all students have been able to achieve it, for level 2 there are 2 students who have not been able and level 3 there are 3 people who did not reach this level while for level 4 there are 5 students who are unable to achieve it. Researchers hope that the teacher who will teach the material to build curved side spaces to pay attention to methods that are suitable for students so that the student learning process does not experience complexity and pay attention to the process of working on problems and drawing conclusions. To increase the level of thinking students on geometry material, build curved side spaces can use teaching aids so that students easily understand.
\end{abstract}

Keywords : build curved side spaces; level thinking Van Hiele

\section{INTRODUCTION}

Learning is the responsibility of every student in seeking knowledge and the quality of learning is determined by the ability of the child himself. Learning can be done by practicing or finding new experiences. Thus students can bring change for themselves, both in the form of knowledge, attitudes and skills. In learning mathematics today there are still many students who think that learning mathematics is very difficult to understand, because students do not like calculations and do not try to solve these mathematical problems.

Mathematics is a language that functions to express a qualitative relationship with space and to make it easier to think as said by Johnson and Myklebusht (1967).

This is the basis of mathematics as the basis of science specifically in exact science. The purpose of learning mathematics in school is to prepare students to be able to use mathematical mindsets in solving problems of everyday life. In the use of this mathematical mindset there are differences and the level of thinking of each student.

Geometry learning is basic learning in mathematics, some of the material contained in geometry, among others: lines, angles, triangles, rectangles, pythagorean 
theorems, tangents, cubes, beams, prisms, pyramid, and jajrgenjang, congruence and congruence, tubes, balls, balls and the cone and its elements that can help solve mathematical problems.

Research conducted by Clements and Bapttista (Budiarto, 2002) on seventh grade junior high school students on learning geometry presents their findings as follows: 1. of the 52 students studied as many as $64 \%$ of students who know that rectangles are ladder level, 2 . Of the 52 people studied there are 26 people or as many as $50 \%$ of students who do not like the evidentiary problem, 3. Most students prefer to solve problems more geometry that is presented visually rather than verbally.

An understanding of learning geometry if students are able to visualize, draw, compare between other shapes and shapes in various positions so that students are quick to understand and easy to remember. Kuswana (2013) argues that thinking is an effort of every individual to reconstruct or manipulate cognitive information that comes from the natural surroundings and from the understanding of symbols stored in human memory.

Student thinking activities occur automatically and become a very important element in the classroom as stated by Saragih (2008). Students in learning mathematics should be directed to think logically and systematically so that students are able to solve their own problems. Mathematical thinking is the main goal of education and becomes a very important aspect in learning mathematics as stated by Isoda and Katagiri (2012). Students who are familiar with the activity of thinking can be seen from the behavior or activities they do. Arend (2009) mentioned in this study that students' thinking abilities will not develop without effort that explicitly and deliberately grows. A student will not be able to develop high-level thinking skills properly without being challenged to practice in the use of learning.

Based on the opinion of experts about thinking above, the researchers conclude that thinking is a process of recalling or constructing information from the surrounding environment and mental processes in solving a problem, someone who is accustomed to thinking activities can be seen from their behavior.

Curved side space is a shape that has a curved section called a blanket or surface surface. Sri Subarinah (2006) states that a space building is a three-dimensional space constrained by a curved shape. Tubes, cones and balls are material that is included in the geometry of the curved side space. The tube is a structure that has 2 circles on the base and the same lid and is connected by a blanket line. The properties of the tubes according to Sumanto et al. (2008) as follows: 1. A tube has three sides namely, a blanket of a tube, the side of the base and cover, 2. The tube does not have an angle, 3 . The tube has two congruent sides, namely the base and the circle cover, 4 . The tube has a blanket line, 5. The tube has a height that is the distance from the base of the lid, 6 . The tube has two curved ribs.

The cone can be defined as a curved side space that resembles a regular $n$-shaped field whose base is circular in shape and the sphere is a curved side space constrained by a curved plane. According to Sumanto et al. (2008) a cone has the following properties: 1. Cone has a circular base, 2. A cone has a curved side called a cone blanket, 3. Cone has two sides, namely its circular base and a curved side or cone blanket, 4 . Cone has a curved rib, 5. Cone has a peak point, 6 . Cone has a height that is the distance from the base and cover. 
The ball can be formed from a semicircular shape rotated 360 degrees at its center line. The van Hiele theory developed by two Dutch educators, Pierre Marie Van Hiele and Dina Van Hiele-Geldof, explains the development of students 'thinking in learning geometry (Abdussakir, 2010). To improve students' thinking abilities on geometry there are three most important elements namely material learning, time and method of preparing learning. Of the three main elements if applied to students in an integrated manner can help students to improve students' thinking stages than before. According to Van Hiele's theory, there are five stages in the development of students' thinking in learning geometry (Abdussakir, 2010). The five stages of Van Hiele geometry thinking are as follows: 1 . level 0 (visualization), students are said to be at level 0 if they only recognize shapes and visions visually, 2. level 1 (analysis), students are said to be at the level of analysis if students are able recognize the properties of arcing, 3. level 2 (abstraction), students are said to be at the level of abstraction if students are able to recognize the properties of arcs and their relationship with other geometries, 4. level 3 (deduction), students said to be able to reach the level of deduction if students are able to draw simple conclusions that are general towards those that are specific, 5. level 4 (rigor), students are said to be at the rigor level if able to draw conclusions and proof.

Based on an explanation of the level of geometry thinking above, the indicators used to measure the level of geometry thinking of Van Hiele in the material of curved side space are as follows:

Van Hiele Geometry Thinking Level Indicator

\begin{tabular}{|c|c|}
\hline $\begin{array}{l}\text { Van Hiele Goemetry } \\
\text { Thinking Level }\end{array}$ & Indicator Van Hiele level thinking geometry \\
\hline $\begin{array}{l}\text { Level : } \mathrm{O} \\
\text { Level of Visualization }\end{array}$ & Students are able to illustrate the picture model \\
\hline $\begin{array}{c}\text { Level : } 1 \\
\text { Level of Analysis }\end{array}$ & $\begin{array}{l}\text { Students are able to recognize the curved side spaces based on the } \\
\text { characteristics of each shape. } \\
\text { Students are able to mention what is known from the test questions }\end{array}$ \\
\hline $\begin{array}{l}\text { Level : } 2 \\
\text { Level of Abstraction }\end{array}$ & $\begin{array}{l}\text { Understanding the relationship between one characteristic with } \\
\text { another in the arising of side curvature. } \\
\text { Questions allow students to write down the question being asked } \\
\text { such as drawing a sketch of a drawing model and being able to } \\
\text { rewrite what is asked of the test questions }\end{array}$ \\
\hline $\begin{array}{l}\text { Level : } 3 \\
\text { Formal Deduction Leve }\end{array}$ & $\begin{array}{l}\text { Students are able to work on problems based on formulas or } \\
\text { definitions that apply in mathematics. } \\
\text { Answers from students are able to detail the completion process }\end{array}$ \\
\hline $\begin{array}{l}\text { Level : } 4 \\
\text { Level Rigor }\end{array}$ & $\begin{array}{l}\text { Students are able to find correct and appropriate conclusions } \\
\text { according to mathematical completion procedures }\end{array}$ \\
\hline
\end{tabular}

The relevant research related to the description of thinking geometry is a study conducted by Lestariyani (2013) said that the Van Hiele geometry thinking stage of Ambarawa $2 \mathrm{~N}$ Middle School students is at level 0 . Only a small proportion of students are at level 2, amounting to $5 \%$ of students. There are $1.91 \%$ of students who are at level 0 . There are $20.10 \%$ of students who do not think level can not be classified in the level of Van Hiele thinking geometry. Overall junior high school students are at level 0 and 1 thinking geometry based on the Van Hiele theorem. 
The researcher chooses Van Hiele geometry as the basis for determining the level of thinking of students in solving geometry problems, another reason researchers choose Van Hiele geometry is as follows.

1. Van Hiele's theory focuses on material geometry

2. Van hiele's theory examines the levels of students' level of thinking in learning geometry

3. Van Hiele's theory explains each level with a general description into a more specialized description.

4. Van Hiele's Theory has a level of accuracy to describe each level of student thinking in learning geometry.

Based on the opinion of the experts above, the authors conclude that the ability to think mathematics is a person's ability to think logically and systematically in dealing with various problems both in mathematics and in solving everyday problems. This ability includes the ability to connect facts and evidence to draw appropriate conclusions. Based on the above background, the author is motivated to conduct research under the title " analysis of students' ability to solve geometrical problems arising from the side curvature based on the level of Van Hiele geometry thinking in class IX students of SMP PGRI Poncokusumo Malang.

The background in this study is how the level of students' ability to solve geometry problems arises from the curved side space based on Van Hiele's level of geometry thinking. The purpose of this study is to describe the level of students' ability to solve geometry problems with curved side spaces based on Van Hiele's level of geometry thinking.

\section{RESEARCH METHOD}

This type of research used in this study is a qualitative descriptive study. In this case, the analysis that will be delivered is about the description of the level of thinking of students in solving geometry problems of curved side space based on Van Hiele's theory. This research was conducted at Poncokusumo Middle School PGRI located on J1 . Raya Paras, Karangnongko, Malang Regency. The subjects used in this study were students of class IX Poncokusumo Malan Middle School consisting of female and male students. The test sheet used by researchers is the Van Hiele Geometry Test (VHGT) consisting of 1 test question used as material to measure students' geometrical thinking abilities based on Van Hiele's geometry, the use of Van Hiele's geometry will indicate the level of student thinking in studying geometry

\section{RESULTS AND DISCUSSION}

The data collection was carried out in Poncokusumo Malang Junior High School, Malang, on Wednesday, March 20, 2019. The researcher gave a question about the geometry material test, especially building curved side spaces.

The questions used in taking research subjects are as follows: 
Pak Niko will make a structure composed of cones, tubes and half balls. If the structure has a diameter of $42 \mathrm{~cm}$, the height of the tube is half of the diameter of the structure, while the height of a cone is $30 \mathrm{~cm} . \pi=\frac{22}{7}$

Determine the drawing model based on what is known?

Calculate the wake up volume?

After the researchers made further observations of the work of students on geometry material to construct curved side spaces, researchers found that students had reached levels 2, 3 and 4. This is the result of research that shows that there is an improvement from the results of previous studies, where previous research according to Lestariyani (2014) is still at the level of analysis or level 2.

\section{Subject Thinking level 1}

Level 0 (visualization)

From the results of the work of subject 1, it appears that students are already familiar with geometric shapes based on their appearance and can model their drawings 42 in accordance with what Sri Rejeki (2014) said where students are able to illustrate their drawing models in the level 0 or visualization category, as shown below.

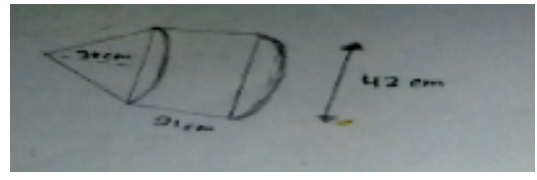

Figure level $0: \mathrm{S} 1$

Level 1 (analysis)

From the results of student work that is subject 1 looks students have been able to write down what is known and look for the height of the tube, because in the test questions are not immediately known the height of the tube, so students are still looking for height based on the question. At this stage students already understand the questions given by researchers so that students easily work on these problems.

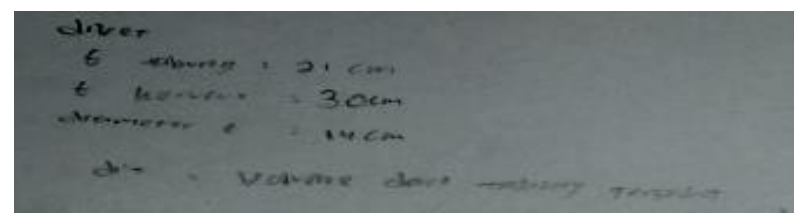

Figure level 1: $\mathrm{S}_{1}$

Level 2 (abstraction)

At this stage students are expected to understand the questions and be able to determine what is asked and write it down as the process of solving test questions. Based on the work of students at this stage 43 are able to understand the questions and write down what is known and the formula as revealed by Nur'ani (2008). 


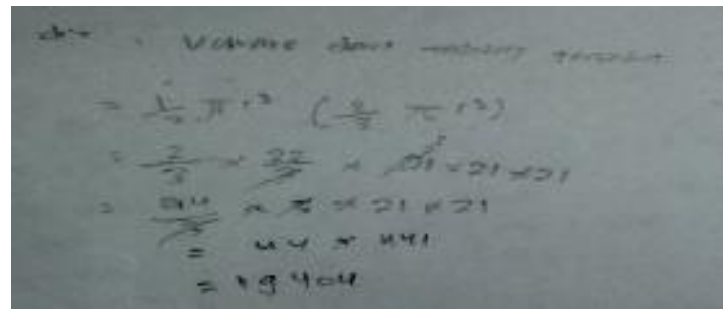

Figure r level 2 : S1

Level 3 (formal deduction)

At this stage students are expected to work on problems according to formulas or definitions that apply in mathematics. After having corrected the work of subject 1 , it seems that they have been able to do the test questions according to the rules that apply in mathematics, reinforced by the level of thinking indicators according to Ferdianto (2010). Like in the picture below

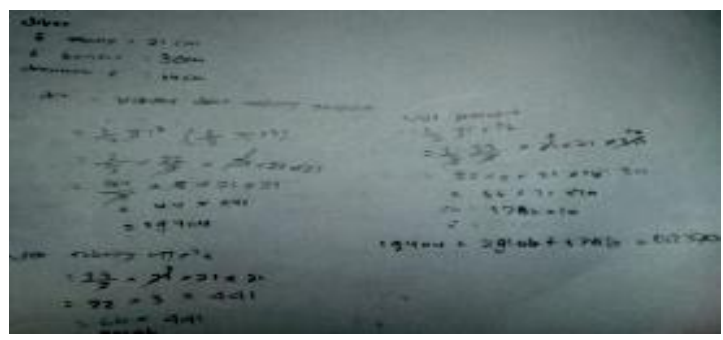

Figure level $3: S_{1}$

Level 4 (rigor)

At this stage students are expected to be able to do the questions well and be able to draw conclusions from the results that have been obtained, if viewed from the work of subject 1 at this stage does not meet because subject 1 does not contain conclusions from the results obtained from the test questions as said by Nur 'Aeni (2008) where students to reach level 4 indicators or rigor must be able to show conclusions and be able to prove it. Like in the picture below.

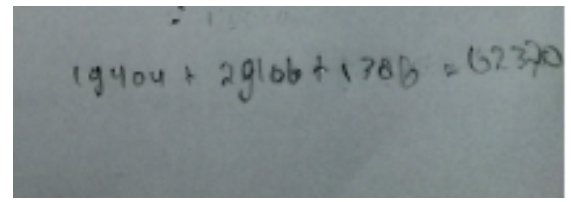

Figure level 4: S1

\section{Subject Thinking Level 2}

Level 0 (visualization)

Based on the results of the work written by subject 2, it can be seen that subject 2 has reached the level of visualization, because subject 2 has shown a drawing model in accordance with requests for test questions provided by researchers. As said by Abdussakir (2010) in Van Hiele geometry level indicator, students say they reach the level of visualization if they can describe the picture model. As shown in the picture below, where subject 2 is able to illustrate the picture model. 


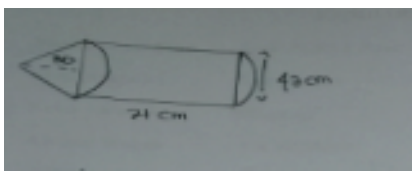

Figure level $0: S_{2}$

Level 1 (analysis)

From the collection of data obtained it appears that subject 2 has understood the purpose of the test questions, in understanding the questions can not be separated from reading, because reading with focus then the questions will be easily understood. Subject 2 seems to have reached the level of analytical thinking because of the answers to the test questions that have been tested subject 2 has understood the purpose of the questions and wrote down what is known and asked according to the sound of Van Hiele's geometry test questions in Nur'aeni (2008). As shown in the picture below, where students are able to correctly understand the meaning of the question sound.

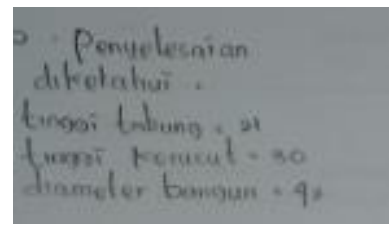

Figure level $1: \mathrm{S} 2$

Level 2 (abstraction)

Based on data collected by researchers shows that subject 2 has shown an abstract way of thinking where students are able to write the relationships between the shapes in accordance with the applicable mathematical formula. Subject 2 looks able to understand the problem and write the formula correctly Nur'aeni (2008). Like in the picture below.

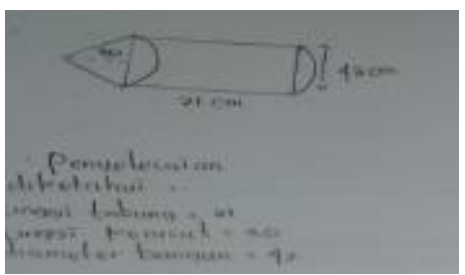

Figure level $2: S_{2}$

Level 3 (formal deduction)

From the results of data collection on subject 2 it can be seen that students are not able to correctly solve test questions such as indicators according to Nur'aeni (2008), because students are not careful in calculating even though in writing the mathematical formula correctly but students are not able to describe the answers correctly. One of the factors that caused subject 2 to not be able to describe correctly was inaccuracy and assumed that the problem was easy to do so that subject 2 had forgotten to write down the answer of one of the volume of the curved side space. As in the picture below where. 


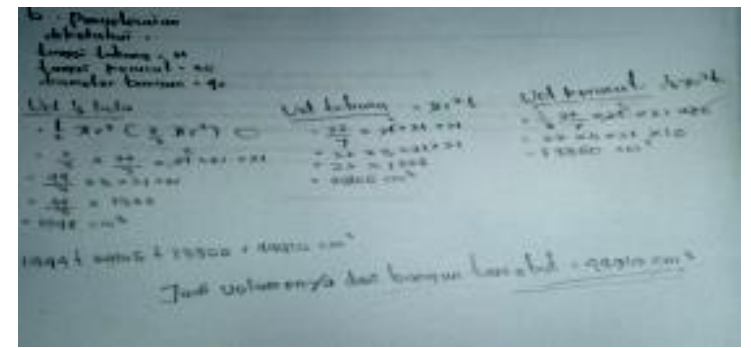

Figure level $3: S_{2}$

Level 4 (rigor)

Based on the answers written by $\mathrm{S} 2$, it can be seen that subject 2 is able to reach the rigor level but is wrong in determining the volume of one of the three structures so that the conclusion is also wrong (Abdussakir, 2010). Where subject 2 does not write in full the volume of the half ball which is actually $19404 \mathrm{~cm}^{3}$ but subject 2 only writes $1944 \mathrm{~cm}^{3}$. Looks like shown in the picture below.

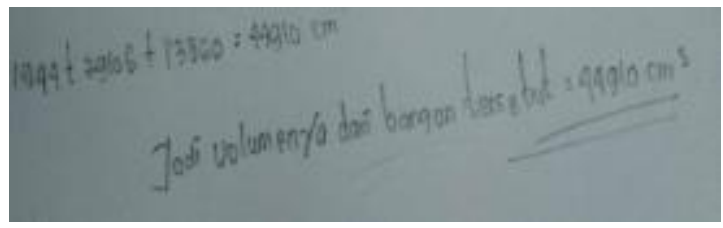

Figure level $4: \mathrm{S}_{2}$

\section{Subject Thinking Level 3}

Level 0 (visualization)

Based on the results of the work of subject 3 on the test questions sheets that have been given by researchers, it appears that subject 3 has no difficulty in completing the questions. At the level of visualization subject 3 can illustrate the drawing model of the curved side space according to the sound problem given by Nur'aeni (2008). As in the picture below which is the work of subject 3 .

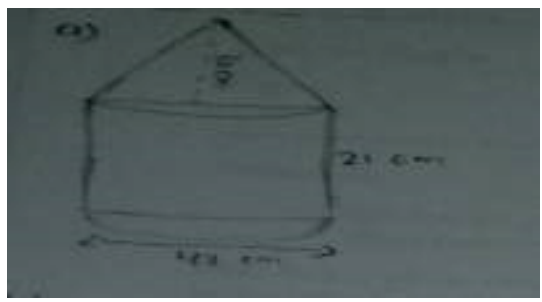

Figure level $0: S_{3}$

Level 1 (analysis)

Based on the work of subject 3 on the test questions given by researchers, it can be said to have been able to reach this level according to the indicators according to Abdussakir (2010) where subject 3 is able to analyze the parts that exist in the curved side space and the characteristics of each shape. proven by describing the drawing model, and being able to understand the problem and mention what is known from the problem. As in the picture below shown by S3. 


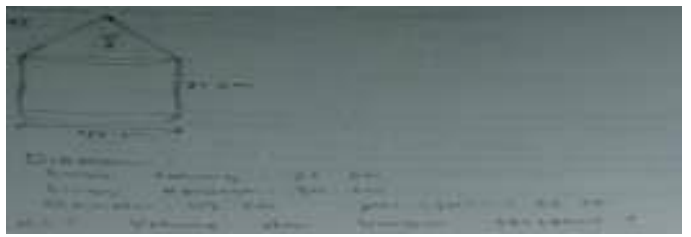

Figure level $1: S_{3}$

Level 2 (abstraction)

Based on the work of subject 3 of the test questions it can be said that students are able to think of abstraction according to statements from Abdussakir (2010) where in these indicators students are said to be able to think of abstraction if students can understand the questions and understand the relationship between the characteristics of the one with the other. Like the results of student work shown in the picture above (level 1 S3 image).

Level 3 (formal deduction)

Based on the data obtained at the time of study, subject 3 was able to reach this level in accordance with what was said by Abdussakir (2010) where students are said to be able to reach level 3 or formal deduction if students work on test questions in accordance with theorems or definitions on the geometry of side space geometry. curvature that applies in mathematics. As shown in the picture below.

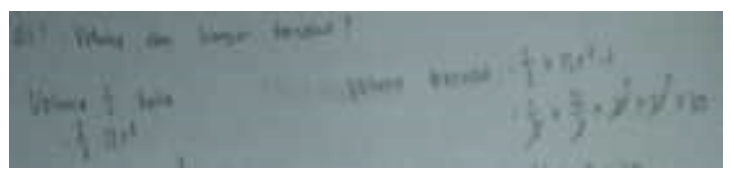

Figure level $3: \mathrm{S}_{3}$

Level 4 (rigor)

Based on the results of the geometry test on subject 3, the work of subject 3 has been corrected, based on data collected that subject 3 is able to reach level 4 or rigor according to the opinion of Abdussakir (2010) where at this level students are said to be able to reach level 4 or rigor if the student able to complete the test questions correctly and can draw conclusions from the results of work on test questions that have been given by researchers. As seen in the picture below.

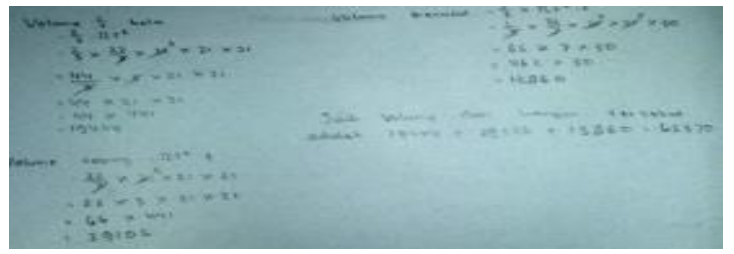

Figure level $4: \mathrm{S}_{3}$

\section{CONCLUSION}

Based on the results and discussion of research in describing the level of students' ability to solve geometrical problems arising from the curved side space based on Van Hiele's level of geometry thinking, the researcher can conclude several things as follows: 
Of the 3 subjects studied showed that students were able to understand and analyze the sound of questions and what was known from the test questions so that they reached level 1 or analysis or by $100 \%$. Subjects 1 and 3 at level 2 or abstraction were able to reach this level because they were able to show abstract definitions and can distinguish the relationship between geometric shapes in geometry and being able to write what is asked in the test questions. Subjects 1 and 3 are able to reach level 3 (deduction) because they are able to write formulas, the completion process is in accordance with the procedures applicable in mathematics. Subject 3 is able to reach level 4 or rigor because it is able to draw conclusions and reasoning from its work on test questions, while for subject 1 and subject 2 are not able to reach this level.

\section{REFERENCES}

Abdussakir. (2010). Pembelajaran Geometri Sesuai Teori Van Hiele. Jurnal Kependidikan dan Keagamaan, Vol VII Nomor 2, Januari 2010, ISSN 16931499.

Arend, B. (2009). Mendorong Berpikir Kritis Dalam Diskusi Berulir Online. The Journal of

Ferdianto, Ferry. (2010). Pembelajaran Geometri Berdasarkan Tahap Berpikir Van Hiele. http://ferrymath.blogspot.com. Akses pada 21 Agustus 2017

Isoda, M., \& Katagiri, S. (2012).Mathematical Thinking: How To Develop It In The Classroom.Journal for Research in Mathematics Education. Vol. 15, No. 1, 8995.

Johnson, D. J, \& Myklebust, H. R. (1967). Learning Disbilities, New York: Grume \& Stratton.Journal on Mathematics Education, 4(1), 75-94.Kreatif Mahasiswa dalam Memecahkan dan Mengajukan Masalah Matematika.(Dissertation).

Kuswana, W. S. (2013). Taksonomi Berpikir. Bandung: PT Remaja Rosdakarya.

Lestariyani, Susi. (2013). Identifikasi Level Berpikir Geometri Siswa SMP Negeri 2 Ambarawa berdasarkan Teori Van Hiele.UKSW. Skripsi Tidak diterbitkan

Mega Teguh Budiarto. (2002). Bentuk kesalahan dalam menyelesaikan permasalahan geometri.surabaya:pusat penelitian IKIP Surabaya.

Nur'aeni. (2008). TeoriVan Hiele Dan Komunikasi Matematika. Materi Semnas Matematika Dan Pendidikan Matematika. PGSD UPI Kampus Tasikmalaya.

Rejeki, S. (2014).Pembelajaran Matematika dengan Pendekatan Teori Van Hiele untuk Meningkatkan Keterampilan Dasar Geometri Siswa Kelas VII C SMP AlIrsyad Surakarta pada Materi Segitiga. Skripsi UNS, Surakarta , 21-22.

Saragih, S. (2008). Mengembangkan Keterampilan Berfikir Matematika. Makalah disajikan dalam Seminar Nasional Matematika dan Pendidikan Matematika, Jurusan Pendidikan Matematika FMIPA UNY, Jogyakarta, 28 Desember 2008.

Sudarmanto. (2010). Tahap Berpikir Siswa BerdasarkanTeori van Hiele dalamBelajar Geometri di KelasVII SMP Negeri 1 Sumber gempol Tulungagung Tahun Ajaran 2011/2012Progam Studi Pendidikan MatematikaJurusan Tarbiyah, STAIN Tulungagung

Sri Subarinah. (2006). Inovasi Pembelajaran Matematika SD. Jakarta: Depdiknas 